\title{
Macroeconomic Variables and Foreign Direct Investment Inflows in Turkey
}

\author{
Saliha Meftah ${ }^{1}$, Abdelkader Nassour $^{2}$
}

\begin{abstract}
Foreign direct investment (FDI) is an essential factor in the development of a country. This study aims to examine what factors influence foreign direct investment. By using the vector error correction model, the research shows that there is a long-term causality relationship between exchange rates and inflation with FDI. However, in the short term, there are no variables that affect FDI. Besides, the Granger causality test shows causality in the direction of GDP and FDI, while other variables do not have causality. This research has implications for policymakers to pay attention to macroeconomic variables in increasing the flow of foreign direct investment.
\end{abstract}

Keywords: foreign direct investment, macroeconomic variables, vector error correction model

\begin{abstract}
Abstrak
Investasi asing langsung (FDI) merupakan salah satu faktor penting dalam pembangunan di suatu negara. Penelitian ini bertujuan untuk menguji faktor apa saja yang memengaruhi investasi asing langsung. Dengan menggunakan model vektor koreksi kesalahan ditemukan bahwa terdapat hubungan kausalitas jangka panjang antara nilai tukar dan inflasi dengan FDI. Akan tetapi, dalam jangka pendek tidak ada satupun variabel yang memengaruhi FDI. Selain itu, uji kausalitas Granger menunjukkkan kausalitas yang searah antara PDB dengan FDI, sementara variabel lain tidak memiliki hubungan kausalitas. Penelitian ini berimplikasi kepada para pengambil kebijakan untuk memperhatikan variabel-variabel makroekonomi dalam meningkatkan arus investasi asing langsung.
\end{abstract}

Kata Kunci: investasi asing langsung, variabel makroekonomi, model vektor koreksi kesalahan

JEL Code: F21, H60

How to Cite:

Meftah, S., \& Nassour, A. (2019). Macroeconomic Variables and Foreign Direct Investment Inflows in Turkey. Signifikan: Jurnal Ilmu Ekonomi, Vol. 8(2), 195-206. doi: http://dx.doi.org/10.15408/sjie.v8i2.10560. 


\section{Introduction}

Nowadays, the issue of foreign direct investment is beginning paid more attention, both at the national and international level. Many theoretical papers look at foreign direct investments (FDI)'s issues. Dunning (1988), Magnier-Watanabe \& Lemaire (2018), and Li \& Tanna (2019) developed primary research on FDI. Economists believe that FDI is an essential element of economic development in all countries, especially in developing ones. Some theories conclude that one of the essential factors of economic growth is a foreign direct investment (Li \& Liu, 2005; Lamsiraroj \& Ulubasoglu, 2015; Carbonell \& Werner, 2018). Some studies found the negative impact of FDI on economic growth (Weisskof, 1972; Susic et al., 2017). Although, Alvarado et al. (2017) found there is no effect of FDI on economic growth in Latin America. Therefore, investment is a determinant factor for economic growth. According to most of the studies that investigated in the relationship between FDI and economic growth found that there is co-integration relationship run between these variables in the long run (Ghazali, 2010; Simionescu, 2016; Kueh \& Yong, 2018; Wattanakul, 2018).

Recently volatile exchange rates make international trade and investment decisions more difficult because volatility increases exchange rate risk. Exchange rate risk refers to the potential to lose money because of a change in the exchange rate. Several empirical studies have investigated the link between exchange rate and FDI inflows. Exchange rate volatility severely affects long-run production costs. Several empirical studies have analyzed the relationship between FDI and exchange rate changes in terms of both the level and volatility (Takagi \& Shi, 2011; Sharifi-Renani \& Mirfatah, 2012; Nishiyama, 2017). Dorantes \& Pozo (2001) shows that foreign direct investment decreased in response to increases in exchangerate uncertainty in the short run. Kiyota \& Urata (2004) found that depreciate the currency of the host country attracted FDI, while the high volatility of the exchange rate discouraged FDI. Cambazoğlu \& Güneş (2016) concludes that there is a co-integration relationship between the exchange rate level and FDI inflows in Turkey.

Concerning the impact of inflation on FDI, there is a few kinds of literature offer some distinctions on the level of inflation. Wint \& Williams (2002) show that a stable economy will attract more FDI. Thus a low inflation environment is desired in countries that promote FDI as a source of capital flow. Additionally, inflation has been hypothesized to distort the tax system that would, in turn, discourage investors for the long run due to money illusion (Omankhanlen, 2011). Furthermore, Bibi et al. (2014) show that there is a long-run relationship between the variables. The inflation rate is negatively related to economic growth. Besides that, the Foreign Direct Investment and trade are considered as a vital element to improve the influence of economic growth.

From the previous studies, it is showing that the debate on the exchange rate is not new for Turkey but expectedly intensify during the economic slowdown periods. However, there have been no studies identified yet which give empirical evidence on the causal relationships between all thus macroeconomic variables (exchange rate, inflation, and GDP) and FDI inflow in Turkey. In another hand, this research chooses Turkey because it has seen significant 
economic improvements in recent years, but it is still not utilizing its potential compared to other major developing economies.

This study aims to fill in this gap in the literature and may be useful for foreign investors and key decision-makers. Additionally, this study proceeds to answer two crucial questions: Firstly, does the Exchange Rate impact the FDI flows into Turkey? Secondly, what is the direction causality run between FDI, Exchange Rate, and Inflation, GDP in Turkey? The purpose of our study is to examine both the long-run relationship and direction of causality between FDI and Exchange rate, inflation and GDP in Turkey during the period 1974-2017.

This paper will contribute significantly to the literature by using recent data on the relationship between macroeconomic variables (exchange rate, inflation, and GDP) and its impact on FDI inflow, in addition, the use of only one country, in this case, Turkey, the results of the study was able to elaborate upon issues that specifically relate to Turkey comprehensively.

\section{Methods}

The study employs secondary data [extracted from World Development Indicators (WDI) and International Country Risk Guide (ICRG), International Featured Standards (IFS), Federal Reserve Bank of St. Louis] for the period 1974-2017 of Turkey. The study based on the assumption that exchange rate and Inflation and GDP effect on FDI inflows in Turkey, for that we use simplified econometric model to apply regression analysis to examine the relationship between this macroeconomic variable, where the model is writing in a single equation time series setup; the model is as follows:

$$
\mathrm{FDI}=\alpha+\beta_{1} \mathrm{REER}+\beta_{2} \operatorname{Inf}+\beta_{3} \mathrm{GDP}+\varepsilon_{\mathrm{t}}
$$

Where: FDI is Foreign Direct investment; REER is Real effective exchange rate; Inf is Inflation; GDP is Gross Domestic Product.

Several econometric methods are used to investigate the relationship between variables mentioned in equation (1). It can summarize as follow: First, we use the Augmented DickeyFuller test to examine the stationary of the variables. Second, to examine the co-integration between the variables, this research using the Johansen test. Next, this research using the VECM model to examine the long-run relationship between the variables. Finally, this research is using the Granger causality test to examine the directional relationship between the variables.

\section{Result and Discussion}

The unit root is an essential test to choose which model is appropriate for the study and to reach this goal, we have used the ADF test. If the variables in the regression model are not stationary, then it can be proved that the standard assumptions for asymptotic analysis will not be valid, the stationary test shows in Table 1 . 
Table 1. Test for Unit Roots Based on ADF test

\begin{tabular}{cccccc}
\hline & & \multicolumn{2}{c}{ Level } & \multicolumn{2}{c}{ First difference } \\
\hline Variable & $\begin{array}{c}\text { Degree of } \\
\text { Integration }\end{array}$ & $\begin{array}{c}\text { Test } \\
\text { Statistics }\end{array}$ & $\begin{array}{c}\text { Critical } \\
\text { value at } 5 \%\end{array}$ & $\begin{array}{c}\text { Test } \\
\text { Statistics }\end{array}$ & $\begin{array}{c}\text { Critical } \\
\text { value at 5\% }\end{array}$ \\
FDI & I(1) & -1.431 & -2.931 & -5.445 & -2.935 \\
REER & $\mathrm{I}(1)$ & -1.751 & -2.931 & -7.156 & -2.934 \\
Inf & $\mathrm{I}(1)$ & -1.653 & -2.931 & -6.920 & -2.933 \\
GDP & $\mathrm{I}(1)$ & 0.439212 & -2.931 & -5.990 & -2.933 \\
\hline
\end{tabular}

*Optimal lag is selected by Schwarz criterion automatically in ADF test. Source: Data processing.

From Table 1, the results reveal that all variables are non-stationary at two lags in the level. This result is because the computed absolute values of the tau statistics $(|\tau|)$ do not exceed the ADF (or MacKinnon) critical tau values, which led a study to fail (or not) to reject the null hypothesis (H0) that there is unit root or the time series is non-stationary. Table 2 also shows that all variables became stationary after the first difference as the computed absolute values of the tau statistics $(|\tau|)$ exceeded the ADF (or MacKinnon) critical tau values, which led a study to reject the null hypothesis (H0). This result as well, means that all variables are integrated of order one, [I (1)].

From Table 2, the test reveals that there is co-integration and there is only one maximum rank of this co-integration it also means that there is one error model exist, and all the variables (FDI, REER, Inf, GDP) are co-integrated. This result suggests that there is one co-integration equation that requires the study to run a Vector Error Correction Model (VECM).

Table 2. Results of Johansen co-integration test

\begin{tabular}{lcccc}
\hline \multicolumn{4}{c}{ Unrestricted Cointegration Rank Test (Trace) } \\
\hline $\begin{array}{l}\text { Hypothesized } \\
\text { No. of CE(s) }\end{array}$ & Eigenvalue & $\begin{array}{c}\text { Trace } \\
\text { Statistic }\end{array}$ & $\begin{array}{c}0.05 \\
\text { Critical Value }\end{array}$ & Prob.** $^{* *}$ \\
None & 0.485914 & 42.88699 & 47.85613 & 0.1353 \\
At most 1 & 0.225610 & 14.94168 & 29.79707 & 0.7839 \\
At most 2 & 0.091021 & 4.203141 & 15.49471 & 0.8865 \\
At most 3 & 0.004631 & 0.194953 & 3.841466 & 0.6588 \\
\hline
\end{tabular}

\begin{tabular}{lcccc}
\hline \multicolumn{4}{c}{ Unrestricted Cointegration Rank Test (Maximum Eigenvalue) } \\
\hline $\begin{array}{l}\text { Hypothesized } \\
\text { No. of CE(s) }\end{array}$ & Eigenvalue & $\begin{array}{c}\text { Max-Eigen } \\
\text { Statistic }\end{array}$ & $\begin{array}{c}0.05 \\
\text { Critical Value }\end{array}$ & Prob.** $^{* *}$ \\
None & 0.485914 & 27.94531 & 27.58434 & 0.0450 \\
At most 1 & 0.225610 & 10.73854 & 21.13162 & 0.6733 \\
At most 2 & 0.091021 & 4.008188 & 14.26460 & 0.8585 \\
At most 3 & 0.004631 & 0.194953 & 3.841466 & 0.6588 \\
\hline
\end{tabular}

Source: Data processing 
Next step, this research is using VECM to examine the relationship among the variables. Table 3 presents the coefficients obtained through the VECM in the long-run relationship and shows that there is one co-integrated equation.

Table 3. The Results of VECM

\begin{tabular}{cc}
\hline Cointegrating Eq: & CointEq1 \\
\hline FDI(-1) & 1.000000 \\
& 21861645 \\
REER(-1) & $(3.7 \mathrm{E}+07)$ \\
& {$[0.59795]$} \\
INF(-1) & 65997851 \\
& $(3.2 \mathrm{E}+07)$ \\
GDP(-1) & {$[2.04188]$} \\
& -0.013524 \\
C & $(0.00242)$ \\
\hline
\end{tabular}

Source: Data Processing

The results presented in Table 3 confirm the long-run relationship between the variables used in this paper. The value of $(\mathrm{C} 1)$ represents the error correction in the VECM, and there is a long-run relationship, the value of $\mathrm{C} 1$ must be negative, and its $\mathrm{P}$-value must also be significant at $5 \%$ levels. Table 3 shows that the error correction coefficient is negative and statistically significant. This result confirms that there is long-run causality running from REER and Inf and GDP to FDI. The value of error correction coefficient approximately about -0.713880 indicates a rapid adjustment process, with almost the whole disequilibrium of the previous year's shock adjusting back to long-run equilibrium in the current year. Table $\mathrm{A}, \mathrm{B}$, and $\mathrm{C}$ in the appendix shows that the value of $\mathrm{R}$-squared is about $45.89 \%$. This result means that the independent variables in the model can explain more than $45.89 \%$ of the variations from the model.

To check if there is short-run causality or not between variables we running Wald Test if P-value of Chi-square is greater than $5 \%$ we accept null hypotheses and vice versa. From the result in Table 4, it can conclude that there is no Short-run causality from REER and Inf and GDP to FDI.

Table 4. Summary of Test Wald results

\begin{tabular}{lll}
\hline Null Hypothesis & P-value & Decision \\
\hline No short run causality from REER to FDI & 0.2798 & Accept the null hypothesis \\
No short run causality from Inf to FDI & 0.2149 & Accept the null hypothesis \\
No short run causality from GDP to FDI & 0.5175 & Accept the null hypothesis \\
\hline
\end{tabular}

Source: Data Processing 
Regarding the diagnostic of residuals, the test results presented in Appendices (Table A $\&$ Table B) showed that the model is well specified with 0.249 probability value of F-statistic. The result concludes that there is no serial correlation (with the Chi-squared value of the 0.153). Table $\mathrm{C}$ in the appendix also shows that there is no heteroskedasticity problem (Breusch-pagan, with a p-value of 0.022 Of Chi-squared).

The result in Table 5 shows that the Granger Causality test indicates a unidirectional relationship between GDP. This finding implies that GDP Granger causes FDI inflow in Turkey. This result is in line with Almfraji \& Almsafir (2014), Lamsiraroj \& Ulubasoglu (2015), Makiela \& Ouattara (2018) that concludes the effect of FDI on growth. Foreign direct investment is associated with higher rates of economic growth (Feeny et al., 2014). However, this result is different from Lamsiraroj (2016) that found a bi-directional relationship between FDI and economic growth. Encinas-Ferrer \& Villegas-Zermeño (2015) also found that the FDI only a marginal influence in economic growth. Makiela \& Ouattar (2018) show that the FDI affects growth via inputs accumulation but not the total factor productivity growth channel. Neto \& Veiga (2013) also shows that the foreign direct investment affects growth through diffusion of technology and innovation.

However, there is no directional causality running from Exchange rate to FDI. This result is different with Kosteletou \& Liargovas (2000), and Phillips \& Ahmadi-Esfahasi (2008) that find the causality runs from the real exchange rate to FDI. Weak host currencies and greater exchange rate volatility will discourage FDI flows (MacDermott, 2008). There is also no directional causality from inflation to FDI inflows. This result is consistent with Alshamsi et al., (2015), which not found the effect of inflation on FDI inflows. Mason \& Vracheva (2017) states that inflation targeting has a positive impact on attracting FDI. Sayek (2009) suggest using investment-smoothing possibility from FDI to reduce the real negative effects of inflation.

Table 5. Granger Causality Test results

\begin{tabular}{lcccc}
\hline Null Hypothesis & F-Statistic & Prob & Type of causality & Decision rule \\
\hline REER does not Granger Cause FDI & 1.30928 & 0.2822 & No causality & Accept $H_{0}$ \\
FDI does not Granger Cause REER & 0.29214 & 0.7484 & No causality & Accept $H_{0}$ \\
INF does not Granger Cause FDI & 2.72307 & 0.0788 & No causality & Accept $H_{0}$ \\
FDI does not Granger Cause INF & 1.21369 & 0.3087 & No causality & Accept $H_{0}$ \\
GDP does not Granger Cause FDI & 7.61415 & 0.0017 & Unidirectional & Reject $H_{0}$ \\
FDI does not Granger Cause GDP & 0.27437 & 0.7616 & No causality & Accept $H_{0}$ \\
INF does not Granger Cause REER & 0.58592 & 0.5617 & No causality & Accept $H_{0}$ \\
REER does not Granger Cause INF & 0.42345 & 0.6579 & No causality & Accept $H_{0}$ \\
GDP does not Granger Cause REER & 0.18846 & 0.8290 & No causality & Accept $H_{0}$ \\
REER does not Granger Cause GDP & 0.15650 & 0.8557 & No causality & Accept $H_{0}$ \\
GDP does not Granger Cause INF & 1.51361 & 0.2334 & No causality & Accept $H_{0}$ \\
INF does not Granger Cause GDP & 0.46204 & 0.6336 & No causality & Accept $H_{0}$ \\
\hline
\end{tabular}

Source: Data processing 
The results from this research do not deviate much from existing literature, the hypothesis of the existence of a co-integration relationship in the long run among variables is accepted similarly in the findings of Dorantes \& Pozo (2001), Bibi et al., (2014), Simionescu (2016), and Kueh \& Yong (2018). Besides that, the long-run causality relationship between REER, Inflation, and GDP towards FDI is consistent with the results of Amoah et al., (2015). This study finds that no short-run causality relationship that runs from Exchange Rate, Inflation and GDP towards FDI in Turkey. Furthermore, the findings of the Granger causality test indicate a unidirectional causality running from GDP towards FDI inflows. This result is contrary to the finding of Bağci \& Ergüven (2016). The Granger causality test also indicated that there is no Granger causality among the rest of the variables; this finding agrees with the results of Amoah et al., (2015).

\section{Conclusion}

The main aim of this study was to examine the impact of Exchange Rate, inflation and GDP on FDI inflows in Turkey between the period of 1974-2017 by using the econometric analysis such as ADF test, Johansen Co-integration test, Vector Error Correction Method (VECM) and Granger Causality test to derive the long-run and short-run relationships among the variables. This study revealed a long-run causality relationship from REER and Inflation and GDP towards FDI. This study finds that no short-run causality relationship that runs from Exchange Rate and Inflation and GDP towards FDI short. Furthermore, the Granger causality test indicates a unidirectional causality running from GDP towards FDI inflows. There is no Granger causality among the rest of the variables.

\section{References}

Almfraji, M. A., \& Almsafir, M. K. (2014). Foreign Direct Investment and Economic Growth Literature Review from 1994 to 2012. Procedia Social and Behavioral Sciences, 129, 206-213. https://doi.org/10.1016/j.sbspro.2014.03.668.

Alshamsi, K. H., bin Hussin, M. R., \& Azam, M. (2015). The Impact of Inflation and GDP per Capita on Foreign Direct Investment: The Case of United Arab Emirates. Investment management and Financial Innovations, 12(3), 132-141.

Alvarago, R., Iñiguez, M., \& Ponce, P. (2017). Foreign Direct Investment and Economic Growth in Latin America. Economic Analysis and Policy, 56, 176-187. https://doi.org/ 10.1016/j.eap.2017.09.006.

Amoah, E., Nyarko, E., \& Asare, K. (2015). FDI, Inflation, Exchange Rate and Growth in Ghana: Evidence from Causality and Co-integrated Analysis. European Scientific Journal, 11(31), 294-304.

Bağci, E., \& Ergüven, E. (2016). Relations Between Interest Rate, Inflation, Growth, and Investment in Turkey, 2002-2015. ISOR Journal of Economics and Finance, 7(5), 43-49.

Bibi, S., Ahmad, S. T., \& Rashid, H. (2014). Impact of Trade Openness, FDI, Exchange Rate, and Inflation on Economic Growth: A Case Study of Pakistan. International Journal of Accounting and Financial Reporting, 4(2), 236-257. 
Cambazoğlu, B., \& Sevcan, G. (2016). The Relationship between Foreign Exchange Rate and Foreign Direct Investment in Turkey. Economics, Management, and Financial Markets, 11(1), 284-293.

Carbonell, J. B., \& Werner, R. A. (2018). Does Foreign Direct Investment Generate Economic Growth? A New Empirical Approach Applied to Spain. Economic Geography, 94(4), 425-456. https://doi.org/10.1080/00130095.2017.1393312.

Dorantes, A., \& Pozo, S. (2001). Foreign Exchange Rate and Foreign Direct Investments in the United States. The International Trade Journal, 15(3), 323-343. https://doi. org/10.1080/088539001753228018.

Dunning, J. H. (1988). The Eclectic Paradigm of International Production: A Restatement and Some Possible Extensions. Journal of International Business Studies, 19(1), 1-31. https://doi.org/10.1057/palgrave.jibs.8490372.

Encinas-Ferrer, C., \& Villegas-Zermeño, E. (2015). Foreign Direct Investment and Gross Domestic Product Growth. Procedia Economics and Finance, 24, 198-207. https://doi. org/10.1016/S2212-5671(15)00647-4.

Feeny, S., Lamsiraroj, S., \& McGillivray, M. (2014). Growth and Foreign Direct Investment in the Pacific Island Countries. Economic Modelling, 37, 332-339. https://doi.org/10. 1016/j.econmod.2013.11.018.

Ghazali. A. (2010). Analyzing the relationship between Foreign Direct Investment, Domestic Investment and Economic Growth for Pakistan. International Research Journal of Finance and Economics, 47, 124-131. https://doi.org/10.13140/2.1.1730.0484

Kiyota, K., \& Urata, S. (2004). Exchange Rate, Exchange Rate Volatility and Foreign Direct Investment. The World Economy, 27(10), 1501-1536. https://doi.org/10.1111/ j.14679701.2004.00664.x.

Kosteletou, N., \& Liargovas, P. (2000). Foreign Direct Investment and Real Exchange Rate Interlinkages. Open Economic Review, 11(2), 135-148. https://doi.org/10.1023/ A: 1008383821669 .

Kueh, J., \& Yong, S. W. (2018). FDI Led Growth in Malaysia: Autoregressive Distributed Lag (ARDL) Bounds Testing Approach. International Business Research, 11(11),46-54.

Lamsiraroj, S., \& Ulubasoglu, M. A. (2015). Foreign Direct Investment and Economic Growth: A Real Relationship or Wishful Thinking. Economic Modelling, 51, 200-213. https://doi.org/10.1016/j.econmod.2015.08.009.

Lamsiraroj, S. (2016). The Foreign Direct Investment-Economic Growth Nexus. International Review of Economics and Finance, 42, 116-133. https://doi.org/10.1016/j.iref.2015.10.044.

Li, X., \& Liu, X. (2005). Foreign Direct Investment and Economic Growth: An Increasingly Endogenous Relationship. World Development, 33(3), 393-407. https://doi. org/10.1016/j.worlddev.2004.11.001.

Li, C., \& Tanna, S. (2019). The Impact of Foreign Direct Investment on Productivity: New Evidence for Developing Countries. Economic Modelling, 80, 453-466. https://doi.org/ 10.1016/j.econmod.2018.11.028. 
MacDermott, R. (2008). Linking Exchange Rates to Foreign Direct Investment. The International Trade Journal, 22(1), 3-16. https://doi.org/10.1080/08853900701784045.

Magnier-Watanabe, R., \& Lemaire, J-P. (2018). Inbound Foreign Direct Investment in Japan: A Typology. Intenational Business Review, 27(2), 431-442. https://doi.org/ 10.1016/j. ibusrev.2017.09.010.

Makiela, K., \& Ouattara, B. (2018). Foreign Direct Investment and Economic Growth: Exploring the Transmission Channels. Economic Modelling, 72, 296-305. https://doi. org/10.1016/j.econmod.2018.02.007.

Mason, R. L., \& Vracheva, V. (2017). The Impact of Inflation Targeting on Attracting Foreign Direct Investment. Journal of Applied Business and Economics, 19(4), 79-94.

Neto, D. G., \& Veiga, F. J. (2013). Financial Globalization, Convergence and Growth: The Role of Foreign Direct Investment. Journal of International Money and Finance, 37, 161-186. https://doi.org/10.1016/j.jimonfin.2013.04.005.

Nishiyama, H. (2017). The Effect of Exchange Rate Fluctuations on Intra-Industry Reallocation in a Firm Heterogeneity Model with Trade and Foreign Direct Investment. The Quarterly Review of Economics and Finance, 64, 32-43. https://doi.org/10.1016/j. qref.2016.09.003.

Omankhanlen, A. E. (2011). The Effect of Exchange Rate and Inflation on Foreign Direct Investment and its relationship with Economic Growth in Nigeria. Economics and Applied Information, 1, 5-16.

Phillips, S., \& Ahmadi-Esfahani, F. Z. (2008). Exchange Rates and Foreign Direct Investment: Theoretical Models and Empirical Evidence. Australian Journal of Agricultural and Resource Economics, 52(4), 505-525. https://doi.org/10.1111/j.1467-8489.2008.00431.x.

Sayek, S. (2009). Foreign Direct Investment and Inflation. Southern Economic Journal, 76(2), 419-443. https://doi.org/10.4284/sej.2009.76.2.419.

Sharifi-Renani, H., \& Mirfatah, M. (2012). The Impact of Exchange Rate Volatility on Foreign Direct Investment in Iran. Procedia Economics and Finance, 1, 363-373. https:// doi.org/10.1016/S2212-5671(12)00042-1.

Simionescu. M. (2016). The Relation Between Economic Growth and Foreign Direct Investment During the Economic Crisis in the European Union. Journal of Economics and Business, 34(1), 187-213.

Susic, I., Trianovic, M. S., \& Susic, M. (2017). Foreign Direct Investment and Their Impact on the Economic Development of Bosnia and Herzegovina. IOP Conference Series: Materials Science and Engineering, 200. https://doi.org/10.1088/1757899X/200/1/012019.

Takagi, S., \& Shi, Z. (2011). Exchange Rate Movements and Foreign Direct Investment (FDI): Japanese Investment in Asia, 1987-2008. Japan and the World Economy, 23(4), 265-272. https://doi.org/10.1016/j.japwor.2011.08.001.

Wattanakul, T. (2018). Analysis of Relationship Between GDP and FDI on the Economic Growth of Laos. Economics World, 6(4), 295-302. 
Wint, A., \& Williams, D. (2002). Attracting FDI to Developing Countries. International Journal of Public Sector Management, 15(5), 361-374. https://doi.org/10.1108/09513550 210435719

Weisskof, T. E. (1972). The Impact of Foreign Capital Inflow on Domestic Savings in Underdeveloped Countries. Journal of International Economics, 2(1), 25-38. https:// doi.org/10.1016/0022-1996(72)90043-8. 


\section{Appendix}

Table A. The result of VECM

\begin{tabular}{|c|c|c|c|c|}
\hline Error Correction: & $\mathrm{D}_{-}(\mathrm{FDI})$ & D_(REER) & $D_{-}(I N F)$ & D_(GDP) \\
\hline \multirow[t]{3}{*}{ CointEq1 } & -0.713880 & $-2.90 \mathrm{E}-10$ & $-9.55 \mathrm{E}-10$ & -2.091139 \\
\hline & (0.19964) & (6.7E-10) & $(1.4 \mathrm{E}-09)$ & $(4.37566)$ \\
\hline & {$[-3.57590]$} & {$[-0.43116]$} & {$[-0.70588]$} & {$[-0.47790$} \\
\hline \multirow[t]{3}{*}{$\mathrm{D}(\mathrm{FDI}(-1))$} & 0.496620 & $2.90 \mathrm{E}-10$ & 3.60E-10 & 2.294807 \\
\hline & $(0.15842)$ & (5.3E-10) & $(1.1 \mathrm{E}-09)$ & (3.47217) \\
\hline & [3.13492] & [0.54392] & [0.33530] & [0.66091] \\
\hline \multirow[t]{3}{*}{$\mathrm{D}(\mathrm{FDI}(-2))$} & -0.010819 & $2.54 \mathrm{E}-10$ & $5.79 \mathrm{E}-10$ & 2.685039 \\
\hline & $(0.18464)$ & (6.2E-10) & $(1.3 \mathrm{E}-09)$ & $(4.04692)$ \\
\hline & {$[-0.05860]$} & [0.40755] & {$[0.46256]$} & [0.66348] \\
\hline \multirow[t]{3}{*}{$\mathrm{D}(\mathrm{REER}(-1))$} & 83985044 & 0.063110 & 0.453818 & $3.88 \mathrm{E}+08$ \\
\hline & $(6.5 \mathrm{E}+07)$ & $(0.21774)$ & $(0.43758)$ & $(1.4 \mathrm{E}+09)$ \\
\hline & [1.30029] & [0.28983] & [1.03711] & [0.27442] \\
\hline \multirow[t]{3}{*}{$\mathrm{D}(\operatorname{REER}(-2))$} & -65639405 & -0.066719 & 0.330190 & $-5.73 E+08$ \\
\hline & $(6.5 \mathrm{E}+07)$ & $(0.21866)$ & $(0.43941)$ & $(1.4 \mathrm{E}+09)$ \\
\hline & {$[-1.01202]$} & {$[-0.30513]$} & {$[0.75144]$} & {$[-0.40289$} \\
\hline \multirow[t]{3}{*}{$\mathrm{D}(\mathrm{INF}(-1))$} & 48533623 & 0.065972 & 0.006452 & $1.52 \mathrm{E}+08$ \\
\hline & $(3.0 \mathrm{E}+07)$ & $(0.10112)$ & $(0.20320)$ & $(6.6 \mathrm{E}+08)$ \\
\hline & [1.61811] & [0.65244] & [0.03175] & [0.23059] \\
\hline \multirow[t]{3}{*}{$\mathrm{D}(\mathrm{INF}(-2))$} & -15520521 & -0.051056 & 0.040106 & $-2.04 \mathrm{E}+08$ \\
\hline & $(3.0 \mathrm{E}+07)$ & (0.10159) & $(0.20416)$ & $(6.6 \mathrm{E}+08)$ \\
\hline & {$[-0.51502]$} & {$[-0.50255]$} & [0.19644] & {$[-0.30837$} \\
\hline \multirow[t]{3}{*}{$\mathrm{D}(\mathrm{GDP}(-1))$} & 0.004922 & $-3.52 \mathrm{E}-11$ & $-3.41 \mathrm{E}-11$ & -0.025466 \\
\hline & $(0.01049)$ & $(3.5 \mathrm{E}-11)$ & $(7.1 \mathrm{E}-11)$ & $(0.22991)$ \\
\hline & [0.46927] & {$[-0.99496]$} & {$[-0.48048]$} & {$[-0.11077]$} \\
\hline \multirow[t]{3}{*}{$\mathrm{D}(\mathrm{GDP}(-2))$} & 0.010832 & $6.56 \mathrm{E}-11$ & $-4.11 \mathrm{E}-12$ & 0.104429 \\
\hline & (0.01070) & (3.6E-11) & $(7.2 \mathrm{E}-11)$ & $(0.23448)$ \\
\hline & [1.01248] & [1.81796] & {$[-0.05668]$} & [0.44536] \\
\hline \multirow[t]{3}{*}{ C } & $-1.75 E+08$ & -1.891304 & 0.711214 & $1.59 \mathrm{E}+10$ \\
\hline & $(5.1 \mathrm{E}+08)$ & (1.70454) & $(3.42543)$ & $(1.1 \mathrm{E}+10)$ \\
\hline & {$[-0.34624]$} & [-1.10957] & [0.20763] & [1.43819] \\
\hline R-squared & 0.495896 & 0.196436 & 0.076380 & 0.048564 \\
\hline Adj. R-squared & 0.349543 & -0.036857 & -0.191768 & -0.227659 \\
\hline F-statistic & 3.388359 & 0.842013 & 0.284843 & 0.175815 \\
\hline Log likelihood & -940.9799 & -141.1521 & -169.7674 & -1067.560 \\
\hline Akaike AIC & 46.38927 & 7.373273 & 8.769139 & 52.56389 \\
\hline Schwarz SC & 46.80721 & 7.791217 & 9.187084 & 52.98184 \\
\hline
\end{tabular}

Source: Data processing 
Signifikan: Jurnal IImu Ekonomi

Volume 8 (2), 2019: 195 - 206

Table B. Breusch-Godfrey Serial Correlation LM Test

\begin{tabular}{cccc}
\hline F-statistic & 1.458002 & Prob. F (2,29) & 0.2493 \\
Obs*R-squared & 3.745964 & Prob. Chi-Square (2) & 0.1537 \\
\hline Source: Data Processing & &
\end{tabular}

Table C. Heteroskedasticity Test: Breusch-Pagan-Godfrey

\begin{tabular}{cccc}
\hline F-statistic & 8.504833 & Prob. F (12,28) & 0.0000 \\
Obs*R-squared & 32.17317 & Prob. Chi-Square (12) & 0.0013 \\
Scaled explained SS & 23.71338 & Prob. Chi-Square (12) & 0.0222 \\
\hline
\end{tabular}

Source: Data Processing 